\title{
Pictorial Representations in Geology Textbooks of High School: a Study in the Paleomagnetism
}

\section{Gina Pereira Correia ${ }^{\circledR}$ Portugal Celeste Romualdo Gomes Portugal}

The pictorial representations (PR) are fundamental in textbooks, particularly to those regarding the Sciences education. Their efficiency and value for the teaching and learning processes must be focus not in their quantity, but in the way they are linked and integrated, so that it can create an adequate relationship with the verbal language. This study presents the results obtained from a quantitative evaluation of Biology and Geology textbooks of the $10^{\text {th }}$ grade $(n=5)$ and Geology of the $12^{\text {th }}$ grade $(n=3)$ of the Portuguese education system. The chosen topic was Paleomagnetism and it was formulated through the following research question: in the chapter concerning Paleomagnetism, do the Geology textbooks show a consistent organization and structuring of the PR for the teaching and learning processes? To answer this question, the following goals were defined, which should be able to evaluate: the relationship of "communication" between the PR and the verbal language in the previously evaluated subchapters; the prevalence of the PR typologies in the observed sample; the presence of legend and scale in the considered PR. The results allow us to conclude the importance that PR has in the Geosciences teaching as a complement to the explanation text, and as a support to the practical activities. However, there are evidences of the lack of rigor in the use of these representations, which can lead to the possibility of a less effective learning of geological subjects or may lead to erroneous conceptions in students.

Keywords: paleomagnetism; pictorial representations; teaching Geology; textbook.

\section{Introduction}

The teaching privileges the use of different forms of language, with a field of verbal and visual language, without forgetting gestural or tactile sign, aimed at specific audiences. However, as the study presented here focuses on the evaluation of textbooks, the kind of language that we will delve into is the visual. A language that enhances learning when used, at the same time, the writing and images in a process called "Multimedia instruction" (Mayer, 2009, p. 4; 2011, p. 427). In this context, highlight external representations of symbols or signs such as pictorial representations (PR), which include the most varied images - photographs, illustrations or drawings, diagrams, charts, maps and stories or narratives (Otero, 2002; Otero, Greca, \& Silveira, 2003). According Klein and Laburú (2009, p. 3), "As imagens podem ser definidas como o resultado do esforço de se abstrair algo e imaginação como a capacidade de decifrar as imagens". The 
images correspond to the visualization of processes that may be real or just numerical simulations and, particularly, in the case of teaching science "desempenham um papel facilitador na explicação de conceitos e são importantes recursos para a comunicação das idéias científicas" (Klein \& Laburú, 2009, p. 2).

Although PR congregate preferences in science, whenever one intends to display relationships and processes that would otherwise be difficult to describe (Cook, 2011), it doesn't only matter the quantity and graphic quality of the images. But also their effectiveness and appreciation for teaching and learning processes should focus on how they are integrated and contextualized, in order to promote an adequate relationship between pictorial representation and verbal language.

Mayer (1993), in a study about the importance of the image as an aid to learning, concluded that images associated with a descriptive verbal explanation generate a higher level of cognitive processing. The same doesn't happen when color images are used for illustrative purposes, and there is a depreciation of the PR that only serve to embellish and, apparently, to make the message support more attractive. In this context, Park and Lim (2007) proved that the illustrations that intend to promote the interest and motivation, do not contribute to the improvement of student learning.

Currently, textbooks appear increasingly enriched pictographically, in a trend that has become more pronounced since the last three decades of the $20^{\text {th }}$ century. A first analysis seems to indicate a growing concern with the graphic aspect, for example larger, more colorful and clear images. However, is this concern related with wanting to increase the didactic and scientific quality of this resource?

The present study intends to contribute to this discussion and has formulated the following research question: in the chapter concerning Paleomagnetism, do the Geology textbooks show a consistent organization and structuring of the PR for teaching and learning process? Thus, the main goals defined, which will enable us to answer the research question are: a) the relationship of 'communication' between the PR and verbal language in sub-chapters analyzed; b) the predominance of typologies of PR (photographs, drawings, diagrams, charts, maps and typologies association) in the sample; c) the presence of legends and scale (only for the photographs) in the PR.

\section{Pictorial representations in textbooks}

Most of the materials prepared for teaching attribute an important role to the use of images and external representations of pictorial character (Otero, Greca, \& Silveira, 2003). Proving its pertinence and application, it's well known that, in the course of a lesson all teachers feel the need to use PR to explain scientific concepts, using these resources as facilitators of the communication process. Parreiral (2011, p.35) states that:

Muitas vezes as imagens são vistas, por professores e alunos, como um método de aprendizagem mais lúdico e menos formal. Poderão também ser entendidas como meios de reiteração dos conhecimentos científicos (apresentados na forma escrita ou oral), ou, ainda, como síntese/resumo desses mesmos conhecimentos. 
However, it is important to evaluate the quality of the images used in the teaching, given that, when they are too playful, they may not contribute to student performance. The use of illustrations for structural understanding (cognitive interest) provides students with a better apprehension of scientific content, rather than using fun texts and illustrations (emotional interest) (Harp \& Mayer, 1997).

In science teaching, the use of PR have been the goal of several studies, of which we emphasize Ametller and Pintó (2002); Cook (2011); Galili (2013); Harp and Mayer (1997); Javier (2006); Klein and Laburú (2009); Laranjeiro, Abrantes, and Gomes (2015); Martins (1997); Martins and Gouvêa (2005); Martins, Gouvêa, and Piccinini (2005); Parreiral, 2011; Parreiral, Pereira, and Gomes (2011); Schmeck, Mauyer, Opfermann, Pfeiffer, and Leutner (2014) and Tauceda, Nunes, and Del Pini (2011). The results show the importance of the use of different typologies of images in teaching and learning processes from the perspective of the teacher and of the student.

However, the proper choice of image and its explanation are essential. In a study with high school students, it was found that they had difficulties in reading scientific images (Ametller \& Pintó, 2002) related to the lack of scientific knowledge necessary for their interpretation and to the absence of legends accompanying the image. Therefore, it's important to analyze how the different image resources influence the comprehension of the message transmitted (Ametller \& Pintó, 2002). Mason, Morphet, and Prosalendis (2006) also state that if, on the one hand, the reading of images happens in an intuitive way, the form of comprehension is superficial and unconscious, which is why it's important to know how the image communicates and transmits the message.

Thus, knowledge of image transmission and communication is even more relevant in science textbooks, since they are didactic resources with a high number and diversity of images that can help students construct concepts and can, therefore, be an important resource for science teachers (Ametller \& Pintó, 2002).

Pictorial representation has been increasingly valued by students, teachers and textbooks writers (Vieira, 2002). Several research studies in the field of science teaching have been carried out with the aim of understanding the impact of visual representations of textbooks and multimedia materials on learning (Cook, 2011).

However, the amount of pictorial representation in a given textbook is not necessarily synonymous with quality. Some researchers even challenge the increasing use of images in textbooks, referring to the fact that there is a common disarticulation between the message conveyed by the illustration and the written text that accompanies it, so in this way they can contribute negatively to the construction of senses and scientific meanings (Otero, Moreira, \& Greca, 2002).

In teaching and learning of geosciences, the quality of the pictorial content is of decisive importance, since there is often a need to transmit specific information and concepts in the form of an image that should be appealing, clear and objective. Specifically, an image out of context or not identified with a legend, can be responsible for the incorrect construction of concepts or ideas. Likewise, a map, a drawing or a 
picture, with no orientation and/or scale, can hamper a correct perception of what this image intends to represent.

The analysis of the PR in the Natural Sciences Portuguese textbooks of the $7^{\text {th }}$ grade, Biology and Geology of the $10^{\text {th }}$ grade and Geology of the $12^{\text {th }}$ grade revealed that, in general, and for the analyzed subjects, there's not always the concern to translate these representations and to contextualize them in the topic to which they refer (Correia \& Gomes, 2010; Laranjeiro, Abrantes, \& Gomes, 2015; Parreiral, 2011; Parreiral, Pereira, \& Gomes, 2011; Parreiral \& Gomes, 2009). Correia and Gomes (2010) works corresponds to a brief study - it was only considered a category of analysis in a universe of three textbooks of the $12^{\text {th }}$ grade - and was a reference to this study, which is more exhaustive and instead considers two categories of analysis in a larger universe of textbooks - eight. All the other studies were developed on different curricular contents of the one that we approach here.

\section{Geology and paleomagnetism in Portuguese high school}

In the Portuguese high school system, the Geology subjects occupy a place in the curriculum for a long time. This tradition has been valued by successive curricular reforms, namely the one implemented during the last decade of the last century (DecretoLei n. ${ }^{\circ}$ 286/89, de 29 de Agosto) and the one that followed (Decreto-Lei n. ${ }^{\circ}$ 74/2004, de 26 de Março), which has been in effect since the first years of the $21^{\text {th }}$ century, and that's still in place. These reforms brought to schools the recognition of the need for an increase of concepts of Geology in the curricula of the disciplines of sciences that, besides integrating only "themes of Life" (knowledge of Biology), began to incorporate "themes of the Earth" (knowledge of Geology) in an equitable way. However, this tradition is not extended to the teaching of paleomagnetism, either because its discovery has little more than half a century and because this theme was reserved for higher education. Thus, for many years, paleomagnetism was a concept that was outside the national curricula of Portuguese high school.

At present, paleomagnetism is a content that integrates formal study plan of the "Geology", which is an optional discipline in the $12^{\text {th }}$ grade - regarding Magnetoestratigraphy, Paleoclimates or the Dynamics of the lithosphere. However, depending on the teacher's will, this content can also be taught in the $10^{\text {th }}$ grade "Biologia and Geology" course, since it is not included in the formal curriculum - teaching the methods for the study of the interior of the terrestrial globe.

\section{Methodology}

\section{Textbooks}

The analyzed textbooks correspond to all the manuals approved by the Ministry of the Education for the subjects under study for the scholastic year 2015/2016, a total of five for BG of the $10^{\text {th }}$ grade and three for Geology of the $12^{\text {th }}$. For the corpus of analysis, 
all the textbooks for the $10^{\text {th }}$ grade are made up of two volumes (one of Biology and one of Geology), according to the subject under study (Figure 1), volume I was chosen, which, in all cases, corresponds to that of Geology.

\begin{tabular}{ll}
\hline School year /Discipline & Theme/Unit \\
\hline $10^{\text {th }}$ BG & $\begin{array}{l}\text { Theme III - Methods for the study of the interior of the } \\
\text { Geosphere }\end{array}$ \\
\hline $12^{\text {th }}$ Geologia & $\begin{array}{l}\text { Theme I - The first steps of a new theory. The Plate Tectonics } \\
\text { Theory }\end{array}$ \\
\hline
\end{tabular}

Figure 1. Selection of the program contents of Biology and Geology (BG) and Geology textbooks.

\section{Qualitative analysis}

In order to fulfill the proposed goals, a qualitative analysis was carried out using an adapted and simplified grid of an instrument developed by Parreiral and Gomes (2009) for the evaluation of PR. The categories, subcategories and items are presented in Figure 2.

With the category "Pictorial representation and relationship with verbal language", it was intended to evaluate the existence, or not, of a textbooks writers concern in establishing the connection between the image and the text to which the knowledge to be explored relates. Thus, each subcategory corresponds to a greater or lesser degree of concern, with a minimum value when, The text makes no reference to the accompanying pictorial representation $(\mathrm{N})$; and a maximum value when, The text refers to the pictorial representation that accompanies it, describing some aspects of the content that it intends to represent $\left(\mathrm{S}^{+}\right)$. Considering the diversity of typologies identified (photographs, drawings/illustrations, diagrams, graphics and maps), it was considered appropriate to add information on their frequency by typology. As far as the photographs are concerned, only those that are individualized are included.

In the category "Aspects related to pictorial representations" it was assessed the presence/absence of legends and/or spatial scale in the PR considered in the previous category. This category was subdivided in two subcategories: Legends and Spatial Scale. In the first one, applied to all the PR considered in this study (photographs, drawings, diagrams, graphics and maps), the evaluative items were: 'Without legends (WL)', when the image has no legends; 'Simple legends (SL)', if there's a reference to the content or process represented, but there is no description; 'Descriptive legends (DL)', whenever a detailed description of the representation is made. Regarding the second subcategory, Spatial Scale, only the photographs were analyzed, and the following parameters were evaluated: 'Without scale (WS)', in the absence of any natural spatial scale (vegetation, a building, ...) or placed by the author (geologist's hammer, coin, ...); and 'With scale

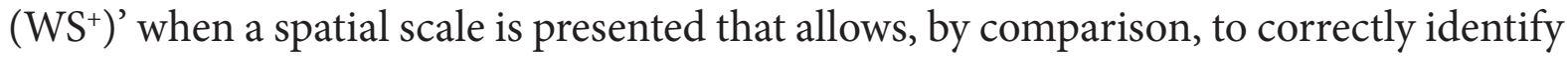
the size of the object or structure that the photograph intends to evidence. 


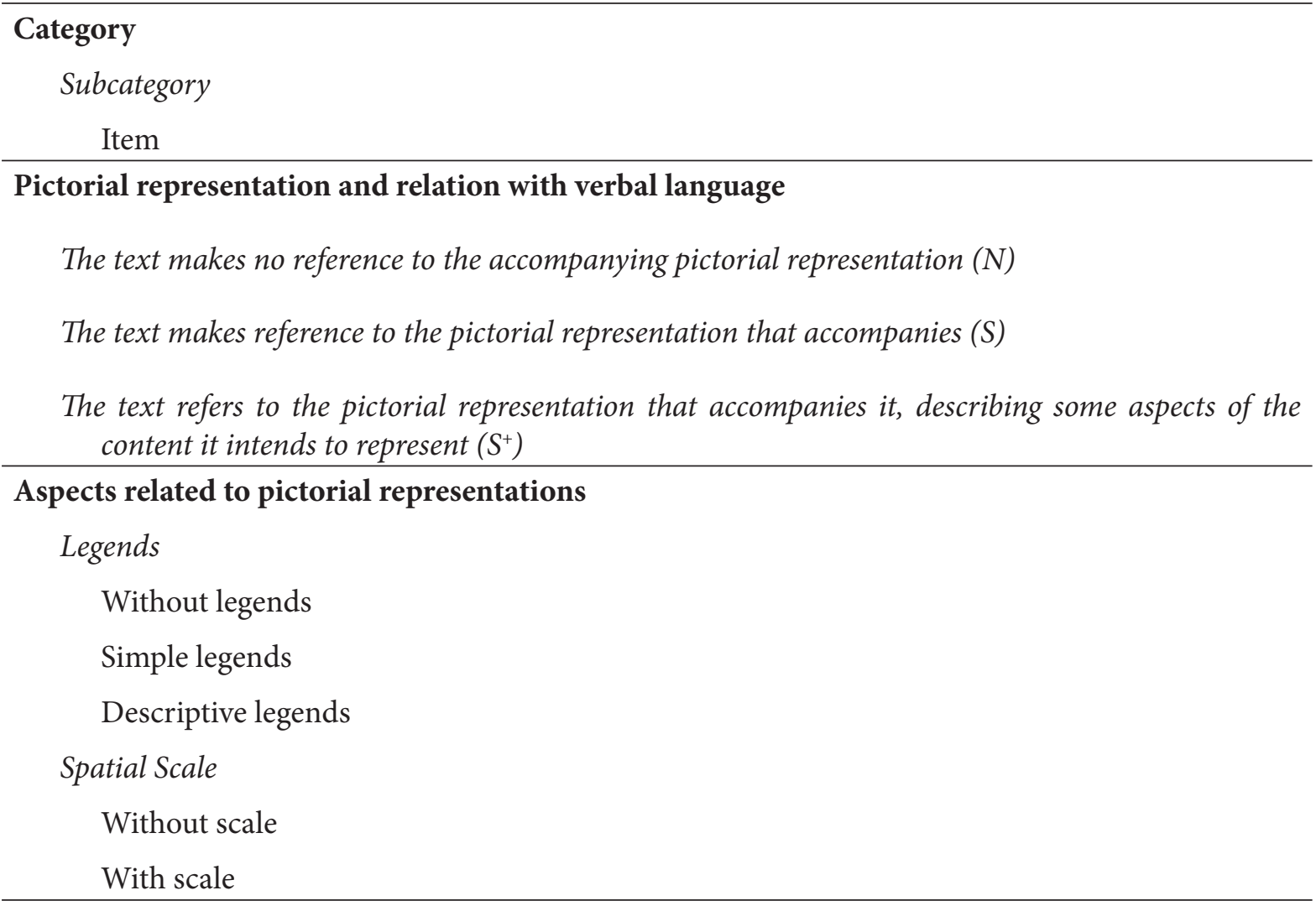

Figure 2. Grid for the evaluation of pictorial representations in textbooks (Adapted from Parreiral and Gomes, 2009)

The analysis of the textbooks was performed in 2 phases and 2 times per phase, individually and together. At time 1 , of each phase, an individual analysis was performed, while at time 2 the individual data were compared and an analysis was carried out in non-concordant cases in order to find a consensual solution. The evaluation of all the textbooks was carried out horizontally to minimize different interpretations of the criteria.

\section{Results and discussion}

\section{Category 'Pictorial representation and relation with verbal language'}

\section{Textbooks of BG $10^{\text {th }}$}

Most of the textbooks analyzed record a frequency of PR that we consider to be relevant and very similar, 10A (14), 10D (15) e 10E (15) (Table 1). Regarding the value of the total frequency of the represented items, a domain of the item $\mathrm{S}^{+}(34)$ was detected in relation to $\mathrm{N}(23)$. 
Table 1. Analyses of the category "Pictorial representation and relation with verbal language" in Biology and Geology textbooks of the $10^{\text {th }}$ grade (frequency)

\begin{tabular}{|c|c|c|c|c|c|c|}
\hline \multirow{2}{*}{ Subcategory } & \multicolumn{5}{|c|}{ Textbook } & \multirow{2}{*}{ 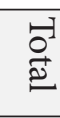 } \\
\hline & $10 \mathrm{~A}$ & $10 \mathrm{~B}$ & $10 \mathrm{C}$ & $10 \mathrm{D}$ & $10 \mathrm{E}$ & \\
\hline $\begin{array}{l}\mathrm{N} \text { - The text makes no reference to the accompanying } \\
\text { pictorial representation }\end{array}$ & 3 & 4 & 6 & 2 & 8 & 23 \\
\hline $\begin{array}{l}S \text { - The text makes reference to the pictorial } \\
\text { representation that accompanies }\end{array}$ & 1 & - & - & - & 1 & 2 \\
\hline $\begin{array}{l}\mathrm{S}^{+} \text {- The text refers to the pictorial representation that } \\
\text { accompanies it, describing some aspects of the content } \\
\text { it intends to represent }\end{array}$ & 10 & 1 & 4 & 13 & 6 & 34 \\
\hline Total & 14 & 5 & 10 & 15 & 15 & 59 \\
\hline
\end{tabular}

The data evidence could indicate that there was some care taken in properly relating the image and text. However, a more detailed analysis shows, that in three of the manuals, the frequency value of item $\mathrm{N}(\mathrm{M} 10 \mathrm{~B}=4 ; \mathrm{M} 10 \mathrm{C}=6 ; \mathrm{M} 10 \mathrm{E}=8)$ is greater than the value of $\mathrm{S}^{+}(\mathrm{M} 10 \mathrm{~B}=1 ; \mathrm{M} 10 \mathrm{C}=4 ; \mathrm{M} 10 \mathrm{E}=6)$. Only the $10 \mathrm{~A}\left(\mathrm{f}(\mathrm{N})=3 ; \mathrm{f}\left(\mathrm{S}^{+}\right)=10\right)$ and $10 \mathrm{D}$ $\left(\mathrm{f}(\mathrm{N})=2 ; \mathrm{f}\left(\mathrm{S}^{+}\right)=13\right)$ textbooks contradict this proportions.

These results deserve a reflection, insofar as the relationship represented by the $\mathrm{S}^{+}$ item, only valued in the $10 \mathrm{~A}$ and $10 \mathrm{D}$ textbooks, is the one that should be considered the most adequate. Although the manuals present a significant amount of images, they do not show the existence of a relation with the accompanying text. In this way, the question of the true usefulness of its incorporation can be raised. Are we dealing with reasons that relate only to the graphic plot of arresting/drawing students' attention? According to Mason, Morphet, and Prosalendis (2006), the use of scientific images, and in the case of textbooks can be so considered, are not intended to call attention or entertain the reader who, in principle, will be interested and will channel their full attention to their interpretation.

The importance of the image as a complement to the optical-graphematic code is undeniable, and its scientific relevance is the responsibility of the textbooks writers and, subsequently, of the users.

Regarding the typology of PR, there is a predominance of 'Drawings' (34) and 'Graphics' (17). On the other hand, with a very reduced frequency, we find the typologies 'Photographs' (4), 'Maps' (3) and 'Diagrams' (2) (Table 2).

Table 2. Typology of pictorial representations in Biology and Geology textbooks of $10^{\text {th }}$ grade (frequency)

\begin{tabular}{ccccccc}
\hline \multirow{2}{*}{ Total } & \multicolumn{6}{c}{ Typology } \\
\cline { 2 - 7 } & Photographs & Drawings & Diagrams & Graphics & Maps & $\begin{array}{c}\text { Association of } \\
\text { typologies }\end{array}$ \\
\hline $64^{*}$ & $4^{* *}$ & $\mathbf{3 4}$ & 2 & 17 & 3 & 4 \\
\hline
\end{tabular}

*Value corresponding to the sum of the various pictorial elements that make up each figure counted in the table 1.

${ }^{* *}$ Were only included figures that are individualized. 
Taking into account the level of schooling and the specific scientific area in which the target study contents fall within, the prevalence of pictograms Drawings and Graphics may be adequate. However, the frequency of 'Diagrams' is deficient, since they are essential for the systematized presentation of concepts. The low frequency of photographs (Table 2) may be due to the specificity of this programmatic content that refers to concepts difficult to photograph. For example, the Earth's magnetic field is an invisible and untouchable concept which, of course, makes impossible obtaining photographic images.

The analysis of the results showed that, in general, the typologies of pictograms used are not diversified. The $10 \mathrm{~A}$ textbook is the one with the greatest diversity of typologies containing photographs, drawings, diagrams, graphics and maps, while the textbook $10 \mathrm{~B}$ only presents drawings. Among typologies considered, only the 'Drawings' is represented in all the textbooks.

Some images correspond to the association of several typologies such as graphs and drawings or the association of these with photographs (Table 2), highlighting the importance of the combination of different pictograms to expose or clarify a particular scientific concept.

\section{Textbooks of Geologia $12^{\text {th }}$}

All Geology textbooks of the $12^{\text {th }}$ grade value the inclusion of numerous images $(\mathrm{M} 12 \mathrm{~A}=24 ; \mathrm{M} 12 \mathrm{~B}=18 ; \mathrm{M} 12 \mathrm{C}=26)$ (Table 3).

However, this valorisation does not occur when analysing the importance of its relation with the description of the contents to which they refer. It should be noted the high frequency with which item $\mathrm{N}$ is recorded in textbooks $12 \mathrm{~A}(22)$ and $12 \mathrm{~B}(18)$, to the detriment of item $\mathrm{S}^{+}$ $(\mathrm{M} 12 \mathrm{~A}=2 ; \mathrm{M} 12 \mathrm{~B}=0)$, showing that, generally speaking, there is no integration of $\mathrm{PR}$ in the text. Only in textbook 12C $\left(\mathrm{f}(\mathrm{N})=9 ; \mathrm{f}\left(\mathrm{S}^{+}\right)=16\right)$, perhaps because it is the most recent edition (2009), most PR are properly identified and contextualized in the text.

Table 3. Analyses of the category "Pictorial representation and relation with verbal language" in the Geology textbooks of the $12^{\text {th }}$ grade (frequency)

\begin{tabular}{|c|c|c|c|c|}
\hline \multirow{2}{*}{ Subcategory } & \multicolumn{3}{|c|}{ Textbooks } & \multirow{2}{*}{ O+ } \\
\hline & $12 \mathrm{~A}$ & $12 B$ & $12 \mathrm{C}$ & \\
\hline $\begin{array}{l}\mathrm{N} \text { - The text makes no reference to the accompanying pictorial } \\
\text { representation }\end{array}$ & 22 & 18 & 9 & 49 \\
\hline $\begin{array}{l}S \text { - The text makes reference to the pictorial representation that } \\
\text { accompanies }\end{array}$ & - & - & 1 & 1 \\
\hline $\begin{array}{l}\mathrm{S}^{+} \text {- The text refers to the pictorial representation that accompanies it, } \\
\text { describing some aspects of the content it intends to represent }\end{array}$ & 2 & - & 16 & 18 \\
\hline Total & 24 & 18 & 26 & 68 \\
\hline
\end{tabular}


Regarding the distribution by typology (Table 4), there is a predominance in the use of 'Drawings' (39) and 'Photographs' (13), revealing that the diversity is greatly reduced.

Table 4. Typology of pictorial representations in Geology textbooks of $12^{\text {th }}$ grade (frequency)

\begin{tabular}{ccccccc}
\hline \multirow{2}{*}{ Total } & \multicolumn{6}{c}{ Typology } \\
\cline { 2 - 7 } & Photographs & Drawings & Diagrams & Graphics & Maps & $\begin{array}{c}\text { Association of } \\
\text { typologies }\end{array}$ \\
\hline $75^{*}$ & $13^{* *}$ & $\mathbf{3 9}$ & 0 & 4 & 12 & 7 \\
\hline
\end{tabular}

*Value corresponding to the sum of the various pictorial elements that make up each figure counted in the table 3.

${ }^{* *}$ Were only included figures that are individualized.

It is important to note the low representativity of the 'Graphics' typology (4), as well as the total absence of 'Diagrams', representations that we consider fundamental for the teaching of geosciences. The first one is important because they imply a degree of abstraction and cognitive development that should be present in the students' competences at the end of high school. The second, because they allow the hierarchical systematization of school subject.

In the textbooks of the $12^{\text {th }}$ grade of Geology, we also come across images that correspond to an association of different pictorial typologies (7). In this case, the relationship between: photographs and drawings; graphics and maps; drawings and maps; or three associated typologies - map, drawing and graphic - are ways to better expose information.

In addition, it was found that in the textbooks of the same year of schooling and of different publishers and in the textbooks of different school years of the same publisher, the images are the same.

\section{Category 'Aspects related to pictorial representations}

\section{Textbooks of BG $10^{\text {th }}$}

The analysis of the results of the category "Aspects related to PR" (Table 7) revealed that in the subcategory, Legends, most images are accompanied by legends, since the total frequency value of the sum of the items 'SL + DL' (35) is greater than that of the item 'LS' (25), and there seems to be an association between the pictorial representation and its legends. However, when we compare the frequency of 'Simple Legends' (26) and 'Descriptive Legends' (9) we find that only the object or structure was identified in the image without any scientific description or content.

It should be noted that the 'Without legends' item is the only one that is represented in all the textbooks, which allows asserting that none of the books puts legends in all of their representations. 
In the $10 \mathrm{~B}$ textbook all pictograms are included in the subcategory 'Without legends' (5) and the 10E textbook is the one that incorporates most 'Without legends' images (10), while the others only have a 'Simple legends' (5).

Table 5. Analysis of the category Aspects related to pictorial representations in Biology and Geology textbooks of the $10^{\text {th }}$ grade (frequency)

\begin{tabular}{|c|c|c|c|c|c|c|c|}
\hline \multirow{2}{*}{ Subcategory } & \multirow{2}{*}{ Item } & \multicolumn{5}{|c|}{ Textbooks } & \multirow{2}{*}{$\begin{array}{l}\vec{O} \\
\vec{D}\end{array}$} \\
\hline & & $10 \mathrm{~A}$ & $10 \mathrm{~B}$ & $10 \mathrm{C}$ & $10 \mathrm{D}$ & $10 \mathrm{E}$ & \\
\hline \multirow{3}{*}{ Legends } & Without legends (WL) & 2 & 5 & 5 & 3 & 10 & 25 \\
\hline & Simple legends (SL) & 8 & - & 5 & 8 & 5 & 26 \\
\hline & Descriptive legends (DL) & 4 & - & - & 5 & - & 9 \\
\hline \multirow{2}{*}{ Spatial scale } & Without scale (WS) & 1 & - & 1 & 1 & - & 3 \\
\hline & With scale $\left(\mathrm{WS}^{+}\right)$ & - & - & - & - & 2 & 2 \\
\hline Total & & 15 & 5 & 11 & 17 & 17 & 65 \\
\hline
\end{tabular}

The textbooks that integrate the image in the text (M10A and M10D) are those that present a lower frequency of 'Without legends' images $(M 10 A=2 ; M 10 D=3)$, although they prefer 'Simple legends' $(\mathrm{M} 10 \mathrm{~A}=8 ; \mathrm{M} 10 \mathrm{D}=8)$ to the detriment of the 'Descriptive Legends' (M10A=4, M10D=5) (Table 1). Although these two use the image in the context of the optical-graphematic code, they turn out to be simplistic in their use by not making a detailed description of the content or process represented.

So, it would be important to have a correct subtitling, although it may not always be more detailed. If there are cases in which descriptive captioning carries information, promoting a clear interpretation, there are others where simple legends may be the most appropriate. For example, if a teacher wishes to evaluate a student's interpretive ability on a pictogram, a descriptive legend may prevent the student from developing that competence.

With regard to the subcategory Spatial Scale, it is verified that most of the photographs appear 'Without scale' (3) and, therefore, it is not possible to evaluate the real dimension of its content. A result that we consider worrying, due to the already mentioned factors on the importance of a scale for the interpretation of the photographic register in geosciences.

The only photographs that have a scale in our sample are found in textbook 10E, probably in an accidental way, since they correspond, in the first case, to the dipping compass used to determine the orientation of the magnetic minerals (M10E, p. 118); in the second, to the furniture of the space in which the object is photographed (M10E, p. 119).

\section{Textbooks of Geologia $12^{\text {th }}$}

The results of the analysis in the 12th grade textbooks indicate that in the M12A and $\mathrm{M} 12 \mathrm{C}$ resources the frequency of the item 'WL' $(\mathrm{M} 12 \mathrm{~A}=4 ; \mathrm{M} 12 \mathrm{C}=10)$ is less than 
the sum of the 'SL+DL' frequency $(M 12 A=20, M 12 C=16)$ (Table 6), although the pictographic content is not legend. Namely, textbook 12A which, although having the largest number of legend pictograms (20), only a minority corresponds to descriptive legends (4).

Table 6. Analysis of the category Aspects related to pictorial representations in Geology textbooks of the $12^{\text {th }}$ grade (frequency)

\begin{tabular}{|c|c|c|c|c|c|}
\hline \multirow{2}{*}{ Subcategory } & \multirow{2}{*}{ Item } & \multicolumn{3}{|c|}{ Textbook } & \multirow{2}{*}{$\begin{array}{l}{ }_{0}^{1} \\
\vec{D}\end{array}$} \\
\hline & & $12 \mathrm{~A}$ & $12 \mathrm{~B}$ & $12 \mathrm{C}$ & \\
\hline \multirow{3}{*}{ Legends } & Without legends (WL) & 4 & 9 & 10 & 23 \\
\hline & Simple legends (SL) & 16 & 8 & 8 & 32 \\
\hline & Descriptive legends (DL) & 4 & 1 & 8 & 13 \\
\hline \multirow{2}{*}{ Spatial scale } & Without scale (WS) & 2 & 3 & 2 & 7 \\
\hline & With scale (WS+) & 3 & - & 4 & 7 \\
\hline Total & & 29 & 21 & 32 & 82 \\
\hline
\end{tabular}

In the subcategory Spatial scale, a frequency equality was detected in the presence and absence of scale, 'WS' (7) and 'WS'' (7) and textbook 12B is the one that offers more photographic representations without scale (3).

Images with scale correspond entirely to the photographic record of personalities associated with the History of Science. While the images without scale refer essentially to equipment photographs and another to an aerial photograph. This item also includes a photograph of an outcrop without any scale, legend or relation to the content of the page and apparently only has a motivational utility.

\section{Conclusions}

The use of PR is important not only in the teaching and learning of geosciences, but also in their correct incorporation in textbooks. Thus, the number of pictograms that compose the BG textbooks of $10^{\text {th }}$ grade and Geology of $12^{\text {th }}$ grade and their diversity, from graphics, drawings, maps, photographs and diagrams, is highlighted, taking into account their existence in the universe of sampling. However, within the textbooks themselves, there is a tendency to repeat two or three typologies to the detriment of the others. Thus, in BG textbooks we note a predominance of drawings and graphics, which we consider to be adequate, insofar as: the first are types of images that are more similar to reality (Parreiral, 2011) and correspond to an efficient language for the understanding of scientific concepts (Costa, Costa, Lima, \& Leite, 2006; Costa, Costa, Leite, \& Lima, 2007; Pereira, Jurbeg, Carvalho, \& Costa, 2008); the second, because they are presented as an efficient methodology in the analysis of information of quantitative nature and, in the establishment of relations between the variables (Parreiral, 2011), very important competences in the teaching of the geosciences. In the textbooks of Geology $12^{\text {th }}$ 
grade the dominant typologies are the drawings and photographs, whose prevalence also seems appropriate, since, according to Parreiral (2011), these are the PR that have a greater analogical relation with the contents or with the reality that they intend to reproduce and, as such, reduce the abstraction inherent in the scientific content taught. It is important to highlight the lack of diagrams that should be included in all textbooks, since they can be used as a methodological resource, hierarchically systematizing the most important points of a subject, providing the user with a more simple and objective reading and, as such, to be promoters of their understanding.

The lack of diversity of the images is also reflected in the fact that we find the same image in different textbooks of the same year and discipline; and the same images in textbooks from different years, but from the same publisher. Both situations must, of course, be a misunderstanding about the importance of the organization and structuring of PR for teaching and learning or, means, the absence of image banks that allow a more varied choice. In this context, we consider that the images should be chosen according to what is intended to represent and not according to what the reader most easily interprets or limitations imposed by the banks of images available for the publishers

Mayer (2011, p. 427) stated that "People learn better from words and pictures than from words alone". Therefore, PR are important as a complement to the text to explain the theoretical contents and are also essential as an integral part of the PA insofar as most of the activities presented in the textbooks are based on the analysis and interpretation of images. In this context, in several situations, an image corresponds to the association of two or more typologies, for example, between photographs and drawings, or drawings, maps and graphics, among others.

The communication relationship between the pictogram and the verbal language is essential and, according to Martins (1997), the images play a significant role in the explanation of scientific concepts. However, it is necessary to take into account the location of the image, as well as an adequate reference in the body of the text that alludes to it. In the BG $10^{\text {th }}$ grade textbooks, the results obtained allow us to conclude that, for the evaluated content and in most textbooks studied, there is no adequate relationship between the image and the text. In these examples, the pictogram is usually used to illustrate a text, but without any description of its content or indication of its presence, which cannot be associated with the antiquity of the textbooks, since the most recent publication textbook (2010) assumes this methodology. There are, however, two textbooks of this discipline and school year that describe the content of the image and present an indication that refers the reader to his observation when reading the written information. From the analysis of the data referring to the textbooks of Geology of the $12^{\text {th }}$ grade, it is concluded that this parameter is also not considered. All the sample integrate a great quantity of images, but only in one of them, the one of more recent edition (2009), the PR is accompanied of a correct reference in the text and its description of its content.

The importance of legends and spatial scale, as a complement of an image, justified 
the assessment of its presence/absence. Regarding the legend, we find that, in the sum of the textbooks sampled, both the BG of the $10^{\text {th }}$ grade and those of the Geology of the $12^{\text {th }}$ grade, no legends all of its pictograms. Specifically, in the BG $10^{\text {th }}$ grade, we also verified that the textbook in which there is a greater care in integrating the image in the text, present a lower frequency of images by legends, which may indicate a concern with the correct use of the PR and the use of the potential of images in the teaching of geosciences. Most of the legends have no explanatory content, but only a simple description of their content. Regarding the Geology textbooks of the $12^{\text {th }}$ grade, there is also a predominance of simple legends over those that describe in detail the visual content.

For the parameter spatial scale, we only consider the type of photography that, although little used in the whole sample, appears absent from special scale in both school years and for the respective disciplines.

The results obtained in this analysis are an alert for the lack of care in the use of the PR in the textbooks of the $10^{\text {th }}$ grade of BG and of the $12^{\text {th }}$ grade of Geology and that can influence the use of the image in the learning of the contents or may induce misconceptions among students.As a final note, we believe that the conclusion of this work could be of added value to those involved in the production of textbooks which may take into account some of these results in the preparation of future editions of these or other manuals that may be developed for school years and subjects analyzed.

\section{Acknowledgements}

CITEUC is funded by National Funds through FCT - Foundation for Science and Technology (project: UID/Multi/00611/2013) and FEDER - European Regional Development Fund through COMPETE 2020 - Operational Programmer Competitiveness and Internationalization (project: POCI-01-0145-FEDER-006922).

\section{References}

Ametller, J., \& Pintó, R. (2002). Students' reading of innovative images of energy at secondary school level. International Journal of Science Education, 24(3), 285-312.

Cook, M. (2011). Teachers' use of visual representations in the science classroom. Science Education International, 22( 3), 175-184.

Correia, G. M. P., \& Gomes, C. R. (2010). O Paleomagnetismo nos manuais escolares de Geologia do $12 .^{\circ}$ ano de escolaridade: actividades práticas e representações pictóricas. e-Terra, 15(31), 1-4.

Costa, M. A. F., Costa, M. F. B., Lima, M. C. A. B., \& Leite, S. Q. M. (2006). O desenho como estratégia pedagógica no ensino de ciências: o caso da biossegurança. Revista Electrónica de Enseñanza de las Ciências, 5(1), 184-191. 
Costa, M. A. F., Costa, M. F. B., Leite, S. Q. M., \& Lima, M. C. A. B. (2007). A construção do conhecimento através de imagens: contribuições para o ensino de ciências. Revista Electrónica de Enseñanza de las Ciencias, 6(1), 20-31.

Decreto-Lei n. ${ }^{\circ}$ 286/89 de 29 de Agosto. Diário da República n. ${ }^{\circ} 198$ - I Série. Ministério da Educação.

Decreto-Lei n. ${ }^{\circ}$ 74/2004, de 26 de Março. Diário da República n. ${ }^{\circ} 73$ - I Série A. Ministério da Educação.

Galili, I. (2013). On the Power of Fine Arts Pictorial Imagery in Science Education. Science \& Education, 22(8), 1911-1938.

Harp, S. F., \& Mayer, R. E. (1997). The role of interest in learning from scientific text and illustration: on distinction between emotional interest and cognitive interest. Journal of Educational Psychology, 89(1), 92-102.

Javier, F. P. P. (2006). Uso (y abuso) de la imagen en la enseñanza de las Ciencias. Enseñanza de las Ciencias, 24(1), 13-30.

Klein, T. A. S., \& Laburú, C. E. (2009). Imagens e ensino de Ciências: análise de representações visuais sobre DNA e biotecnologia segundo a retórica da conotação. In Anais VII Encontro Nacional de Pesquisa em Educação em Ciências (p. 1-12). Florianópolis, Brasil: ABRAPEC.

Laranjeiro, R. M., Abrantes, I., \& Gomes, C. R. (2015). Representações pictóricas nos manuais escolares de Ciências Naturais do 7. ${ }^{\circ}$ ano: Terra - Um planeta com vida e Dinâmica interna da Terra. In H.G. Pinto, M. I. P. S Dias, R.G. Muñoz, (Orgs.), Atas IV Conferência Internacional Investigação, Práticas e Contextos em Educação (p. 136-145), Leiria: Escola Superior de Ciências Sociais, IPL.

Martins, I. (1997). O papel das representações visuais no ensino-aprendizagem de ciências. In Atas Encontro de pesquisa em Ensino de Ciências (pp. 366-373), Águas de Lindóia, SP.

Martins, I., \& Gouvêa, G. (2005). Analisando aspectos da leitura de imagens em livros didáticos de ciências por estudantes do ensino fundamental no Brasil. Enseñanza de las ciencias(número extra - VII Congresso), 1-3.

Martins, I., Gouvêa, G., \& Piccinini, C. (2005). Aprendendo com Imagens. Ciência e Cultura, 57(4), 38-40.

Mason, R., Morphet, T., \& Prosalendis, S. (2006). Reading Scientific Images: The Iconography of Evolution. Cape Town: HSRC Press.

Mayer, R. E. (1993). Illustrations that instruct. In R. Glaser (Ed.), Advances in instructional psychology (Vol. 4). Hillsdale, NJ: Erlbaum. 
Mayer, R. E. (2009). Multimedia learning (2 ed.). New York: Cambridge university Press Mayer, R. E. (2011). Instruction Based on Visualizations In R. E. Mayer \& P. A. Alexandre (Eds.), Handbook of research on learning and instruction (pp. 427-445). New York: Routledge.

Otero, M. R. (2002). Imágenes y Enseñanza de la Física: Una visión cognitiva. Doctoral, Universidad de Burgos, Burgos.

Otero, M. R., Moreira, M. A., \& Greca, I. M. (2002). El uso de imágenes em textos de física para la enseñanza secundaria y universitária. Investigações em Ensino de Ciências, $7(2), 127-154$.

Otero, M. R., Greca, I. M., \& Silveira, F. L. (2003). Imágenes visuales en el aula y el rendimiento escolar en Física: un estudio comparativo. Revista Electrónica de Enseñanza de las Ciencias, 2(1), 1-30.

Park, S., \& Lim, J. (2007). Promoting positive emotion in multimedia learning using visual illustration. Journal of Educational Multimedia and Hypermedia, 16(2), 141-162.

Parreiral, R. C. (2011). Representações para o Ensino e a Aprendizagem de Temas de Geologia no Ensino Básico e no Ensino Secundário. Doutoramento Universidade de Coimbra, Coimbra.

Parreiral, R. C., \& Gomes, C. R. (2009). Representações pictóricas nos manuais de ensino de Ciências Naturais do 7. ${ }^{\circ}$ ano de escolaridade. In Atas XIII Encontro Nacional de Educação em Ciências (pp. 953-962.), Castelo Branco: Escola Superior de Educação do IPCB.

Parreiral, R., Pereira, L. G., \& Gomes, C. (2011). Representações pictóricas nos manuais de ensino de Ciências Naturais ( $7 .^{\circ}$ ano) e de Geologia (10. ${ }^{\circ}$ ano). In L. J. P. F. Neves, A. J. S. C. Pereira, C. S. R. Gomes, L. C. G. Pereira \& A. O. Tavares (Eds.), Modelação de sistemas geológicos: livro de homenagem ao Professor Manuel Maria Godinho (pp. 291301). Coimbra: Laboratório de Radioactividade Natural da Universidade de Coimbra.

Pereira, M. E. C., Jurbeg, C., Carvalho, P. R., \& Costa, M. A. F. C. (2008). A construção do conceito científico de biossegurança através da linguagem gráfica. In L.R. Oliveira, L. M. Latini (Coor.). Anais do Encontro Nacional de Ensino de Ciências da Saúde e do Ambiente (pp. 8-18), Niterói, Rio de Janeiro: UNIPLI.

Schmeck, A., Mayer, R. E., Opfermann, M., Pfeiffer, V., \& Leutner, D. (2014). Drawing pictures during learning from scientific text: Testing the generative drawing effect and the prognostic drawing effect. Contemporary Educational Psychology, 39(4), 275-286.

Tauceda, K. C., Nunes, V. M., \& Del Pini, J. C. (2011). O Livro Didático e as Representações Mentais de Bioquímica e Biofísica em Alunos do Ensino Médio (The textbook and students' mental representations in biochemistry and biophysics at secondary education). Experiências em Ensino de Ciências, 6(1), 57-68. 
Vieira, C. T. (2002). O Ensino das Ciências no Ensino Básico: Perspectiva histórica e tendências actuais. Viseu: Escola Superior de Educação Jean Piaget.

\section{Analysed textbooks}

Dias, A. G., Guimarães, P., \& Rocha, P. (2005). Geologia 12. Porto: Areal Editores.

Félix, J. M., Sengo, I. C., \& Chaves, R. B. (2006). Geologia 12. ${ }^{\circ}$ Porto: Porto Editora.

Ferreira, J., \& Ferreira, M. (2007). Planeta com Vida 10. ${ }^{\circ}$. Carnaxide: Santillana Constância.

Marques, M. (2007). Uma Breve História Natural da Terra 10. ${ }^{\circ}$. Rio Tinto: Edições ASA. Matias, O., Martins, P., Dias, A. G., Guimarães, P., \& Rocha, P. (2009). Biologia e Geologia 10. ${ }^{\circ}$ Porto: Areal Editores, SA.

Oliveira, Ó., Silva, J. C., \& Ribeiro, E. (2009). GeoDesafios. Porto: Edições ASA.

Ribeiro, E., Silva, J. C., \& Oliveira, Ó. (2007). Desafios 10. ${ }^{\circ}$. Rio Tinto: Edições ASA.

Silva, A. D., Mesquita, A. F., Gramaxo, F., Santos, M. E., \& Baldaia, L. (2010). Terra Universo de Vida $10 .^{\circ}$. Porto: Porto Editora.

\section{Gina Pereira Correia}

orcid.org/0000-0002-0269-7564

Centro de Investigação da Terra e do Espaço da Universidade de Coimbra (CITEUC)

Coimbra, Portugal gina_maria@sapo.pt

Celeste Romualdo Gomes

+ She passed away on January, 2016

Universidade de Coimbra

CITEUC, DCT

Coimbra, Portugal

Submitted on 24th July 2016

Accepted on 22nd November 2016

Published on 31st August 2017 